\title{
STRATEGY OF DISTRIBUTION VARIATION TO VOLUME OF LIGHT FOOD SALES ON MANDALA TRADING COMPANY IN CIPAKU-CIAMIS REGENCY
}

\author{
Tazkiyah Ainul Qolbi \\ Institut Agama Islam Darussalam (IAID) Ciamis-Jawa Barat \\ Email: tazkiyah.ainulqolbi@iaid.ac.id \\ Rohimat Rudiansyah \\ Institut Agama Islam Darussalam (IAID) Ciamis-Jawa Barat \\ Suci Sulastri \\ Institut Agama Islam Darussalam (IAID) Ciamis-Jawa Barat
}

\begin{abstract}
This research was conducted to find out the influence of distribution channel cost to sales volume. This research was conducted on a snack food company that survived since 1992 until today and has increased from year to year with the marketing strategy it uses. The types of distribution channels used are the Mandala Cipaku Ciamis Trading Company so well that it can increase the productivity of the company. The method of analysis used in this research is descriptive verivikatif method with correlational research method. Sources of data used in this study is secondary data in the form of corporate financial statements of 2017-2020. The author uses two variables, namely the variable $\mathrm{X}$ as the independent variable is the cost of disstribusi channel and variable $\mathrm{Y}$ as the dependent variable is the sales volume. Statistical analysis method used by writer is Kolmogorov Smirnov normality test and Simple Linear Regression by testing the hypothesis used is Coefficient of Determination (R2) and Test t (Partial Test). Based on the research results, it can be concluded that: The cost of distribution channels and sales volume of PD Mandala Cipaku Ciamis year 2017-2020 jointly experienced an average increase of $10 \%$ achieved the company using the type of distribution channels indirectly by continuing to increase the number of distributors in the cities that are marketing goals. The amount of distribution channel cost incurred by PD Mandala Cipaku Ciamis have a positive and significant effect to the increase of company's sales volume based on the result of quantitative analysis with correlation coefficient value (r) of 0.993 indicates a very strong relationship level, meaning the relationship between distribution channel and sales volume is direction. And the value of determination coefficient (R2) is $98,6 \%$ and the rest $1,4 \%$ influenced by other factor outside this research. Hypothesis testing using $t$ test shows that the independent variable has a strong and significant influence on the dependent variable.
\end{abstract}

\begin{tabular}{l} 
Abstrak \\
Penelitian ini bertujuan untuk mengetahui pengaruh biaya saluran distribusi terhadap \\
volume penjualan. Penelitian ini dilakukan pada sebuah perusahaan makanan ringan \\
yang bertahan sejak tahun 1992 hingga saat ini dan mengalami peningkatan dari tahun \\
ke tahun dengan strategi pemasaran yang digunakannya. Metode penelitian yang \\
digunakan adalah metode deskriptif verivikatif dengan metode penelitian korelasional. \\
Data terdiri atas data sekunder berupa laporan keuangan perusahaan tahun 2017- \\
2020. Penulis menggunakan dua variabel, yaitu variabel X sebagai variabel bebas \\
adalah biaya saluran distribusi dan variabel Y sebagai variabel terikat adalah volume \\
penjualan. Hasil penelitian menunjukkan bahwa: Biaya saluran distribusi dan volume \\
\hline https://riset-iaid.net/index.php/SE
\end{tabular}


penjualan PD Mandala Cipaku Ciamis tahun 2017-2020 secara bersama-sama mengalami kenaikan rata-rata $10 \%$ yang dicapai dengan menggunakan jenis saluran distribusi secara tidak langsung dengan terus melakukan penambahan jumlah distributor di kota-kota yang menjadi tujuan pemasaran. Besarnya biaya saluran distribusi yang dikeluarkan oleh PD Mandala Cipaku Ciamis berpengaruh positif dan signifikan terhadap peningkatan volume penjualan perusahaan berdasarkan hasil analisis kuantitatif dengan nilai koefisien korelasi (r) sebesar 0,993 menunjukkan tingkat hubungan yang sangat kuat, artinya hubungan antara saluran distribusi dan volume penjualan adalah arah. Dan nilai koefisien determinasi (R2) sebesar 98,6\% dan sisanya sebesar $1,4 \%$ dipengaruhi oleh faktor lain di luar penelitian ini. Pengujian hipotesis dengan menggunakan uji $\mathrm{t}$ menunjukkan bahwa variabel independen memiliki pengaruh yang kuat dan signifikan terhadap variabel dependen.

Keywords: Distribution Channel, Distribution Channel Type, Sales Volume

\section{Introduction}

Companies realize that competition in the same industry more competitive. This is marked by the number of local and international products available on the market increasingly diverse. Therefore a good distribution channel strategy is needed so that consumers can easily get the expected product. If the company's distribution channel is right then the sales will run smoothly and the company will make a profit.

The determination of distribution channels as an element of the distribution mix is considered to be one of the critical activities facing corporate managers as it can affect all other marketing decisions, such as decisions about products, prices, promotions, and so on. In addition, the selection of distribution channels will involve decisions regarding the use of dealers or marketing brokers such as wholesalers, agents, brokers, retailers and other types of dealers and how to establish good and mutually beneficial relationships with such intermediaries or distributors over the long term.

Based on research conducted by Sari (2019) with the title Influence Channel Distribution Against Sales Volume of Cement Products PT. Semen Tonasa In Pangkep with the results of quantitative analysis showed that based on the results of multiple regression analysis obtained equation: $\mathrm{Y}=(-5052,710)+3,410 \mathrm{X} 1+(-4,867) \mathrm{X} 2+$ $109,894 \mathrm{X}_{3}$. The most dominant variable affecting sales volume is variable of number of packing plant $\left(\mathrm{X}_{3}\right)$ with coefficient equal to 109,894. The value of adjuted determination coefficient $\mathrm{R}$ Square is 0,999 , it means all independent variable that is Distribution Cost (X1), Number of Distributors (X2), Number of Packing Plant ( $\mathrm{X}_{3}$ ) have contribution together $99,9 \%$ to dependent variable (Y) sales volume. The remaining $0.1 \%$ is influenced by other factors not included in the study. Hypothesis testing using t test shows that each independent variable has a strong and significant influence on the dependent variable.

The importance of distribution channels within a company in an effort to expand market share that will result in increased sales volume in any company. Selection of distribution channel types will give an idea of the company's sales volume, because the longer the distribution channel used to eat the higher the volume of sales.

Based on these descriptions, the authors try to do research on the magnitude of the influence of the cost of distribution channels diap likilah by a company engaged in the sale of snack PD Mandala Cipaku Ciamis in marketing the resulting product marketed to out of town. Given the importance of this research is done to determine the 
role of distribution channel costs in delivering products to consumers in order to increase the company's sales volume.

\section{Theoretical Review}

\section{Marketing Concepts}

Marketing is a human activity that aims to satisfy the needs and desires of the subscription through the exchange process and the parties concerned with the company. marketing is also an activity of the company in making plans, determining prices, promoting and distributing goods and services "(Sunyoto, 2017: 19). According Syakir (2006: 12) "marketing strategy is a statement (both explicit and implicit) about how a brand or product line reaches its goal".

It can be concluded that the marketing strategy is a set of objectives and targets, policies and rules that provide direction to marketing efforts from time to time, at each level and reference and allocation, especially as the company responds to the environment and changing circumstances of competitors. In a marketing strategy a company or institution needs to determine the target market and associated marketing mix.

Marketing in an Islamic Perspective

According to Alma \& Priansa (2011: 340) "Islamic marketing is a strategic business discipline that directs the process of creating, offering, and changing values from one initiator to stakeholders in the overall process in accordance with the covenants and principles of the Qur'an and Hadith “. Rasulullah SAW has taught his people to trade by upholding Islamic ethics. In economic activity, Muslims are prohibited from taking a false action.

Shariah market is an emotional market where people are attracted for religious reasons not because of financial gain alone, nothing contradicts the principles of muamalah he contains the values of worship, as the word of God is: "Say, verily my worship, my worship, my life and my death is for Allah, the Lord of the Worlds" (Q.S. Al-An'am, 6: 162).

Trade is important in Islam, so important that Allah appointed Muhammad as a very successful merchant before he was appointed prophet. This shows Allah SWT teaches with honesty done by Muhammad bin Abdullah when he became a trader that his trade was not a loss, but instead made him a successful entrepreneur. There are several traits that make the Prophet Muhammad successful in doing business that is shiddiq (honest or true), amanah (trustworthy), fathanah (intelligent) and tabligh (communicative).

The principles of Islamic marketing according to Gymnastiar and Kertajaya (2004: 46) are: Be fair and responsive to change, do the best in terms of products and prices, willingly willing and kiyar rights to the buyer (the right of cancellation of the transaction), not cheating, and oriented to quality. According to Kartajaya \& Sula (2006: 77) there are several characteristics of sharia marketing that can be a guide for marketers, namely divinity (rabbaniyah), ethics (akhlaqiyyah), realistis (alwaqi'iyyah) and humanistis (al-insaniyyah).

According Rangkuti (2002: 111) "marketing mix strategy is designed to achieve marketing objectives". As the heart of the marketing plan, the marketing mix strategy 
should include at least the following things: the products and services we produce, what price we will sell to the consumer, how the promotion strategy can increase awareneass of products / services we produce in the middle competition and how this product is distributed. According to Sutojo (2009: 237) "distribution activities that deliver products from the manufacturer to the desired location or closest to the buyer, the terms of various marketing activities. To carry out the function requires substantial human and financial resources“. According to Kotler (2007: 141) that members of distribution channels have several main functions, namely informal function, promotion function, negotiation function, ordering function, financing function, risk taking, physical ownership, payment and property rights.

According Kasali (2017: 156) distribution channels are the most widely used for the distribution of goods and services are as follows: (1) channel 1 user manufacturer; (2) channel 2 consumer reseller manufacturer; (3) channel 3 wholesale manufacturer/retailer sales consumer; and (4) channel 4 manufacturer agent / broker wholesale consumer retailer. As for the forms of distribution channels according to Gitosudarmo (2008: 309) can be divided into several kinds.

a. Direct Distribution Channels

In a direct distribution channel the entrepreneur attempts to channel the goods purchased by the consumer directly to the consumer's premises. Thus, it is expected that consumers will feel satisfied because consumers no longer need to think about the problem of transporting goods bought it their home.

b. Indirect Distribution Channels

In this case employers use outsiders to help channel their goods to consumers. The outsider is a dealer or broker (Middle Man). This way of indirect distribution is generally done by other entrepreneurs engaged in trading or distribution of goods.

7. Factors Affecting the Selection of Distribution Channels

Things to consider according to Tjiptono (2008: 189) include consideration of markets, products, intermediaries, and companies.

1) Market Considerations (type of market, number of potential customers, market geographic concentration, number and size of bookings)

2) Product Considerations (unit value, perishability and technical nature of the product)

3) Considerations of Intermediaries (services provided by intermediaries, the existence of desired intermediaries and intermediary attitudes towards company policy

4) Company Considerations (financial resources, management capabilities, desired level of control, services provided by the seller and the environment

Sales is a commercial transaction or transfer of commercial rights to goods and services which in principle involve two parties namely sellers and buyers (Swastha \& Irawan, 2005: 406). Furthermore, according to Swastha (2005: 65) argues that "sales volume is the net sales of the company's earnings report. net sales are obtained through the sale of all products (line product) over a certain period of time and the proceeds of sales achieved from the market share (market share) which is a potential sale that may consist of a group of buyers over a period of time. Based on this understanding is known that the volume of sales is the result of the total amount of goods that have been sold by the company regarding the results of its production.

9. Distribution Channel Relationship with Product Sales 
Determination of the distribution channel chain is very important, because it will affect the smoothness of sales, profit levels, capital, risk, and others. "Distribution is an activity that should be done by the entrepreneur to distribute, distribute, transmit, and deliver goods that are marketed to consumers. The main reason for using intermediaries is because intermediaries can help improve distribution efficiency "(Swashta \& Irawan, 2005: 289). Thus, the greater the number of merchants will increase sales volume, as more and more big traders the level of relationship with consumers who are increasingly high in promoting products and providing information is also more and more.

\section{Methods}

The research method used in this research is using descriptive research method verivikatif. According to (Sugiyono, 2019: 7-8) descriptive research method is a study conducted to describe independent variables, either on one or more variables (standalone variables) without making a comparison and look for that variable with other variables. While verivikatif method is defined as research conducted on a particular population or sample with the aim of testing the hypothesis that has been established.

Quantitative research with correlational research approach. "The purpose of correlational research is to detect the extent to which variations in a factor relate to variations on one or more other factors based on the correlation coefficient" (Suryabrata, 2004: 82). This correlational method is a continuation of descriptive method, where in this method the relationship between variables is studied and explained.

To support the discussion in hypothesis testing that has been previously described, then the type and source of data required are: (1) Primary data, which is a collection of information obtained by researchers directly from the location of the study through the first source (respondents or informants) or through the results of observations made alone (Martono, 2020: 65). This data is obtained directly from the head of the company, administrative staff and distribution staff.(2) Secondary data, which is data obtained from other sources that serve as supporting data (Martono, 2020: 66). The data taken for this research is sourced from company financial statement data which contains data from variable $(\mathrm{x})$ that is distribution cost and variable (y) of sales volume per start from 2017 until 2020.

Data collection techniques used for solving and analyzing the problems posed in this study are: (1) Observation. Observation of data collection techniques by noticing something with the eye. According to Sujarweni (2019: 75), "observation is a systematic observation and recording of symptoms that appear on the object of research". In relation to data collection, this method will be carried out with direct observation of the activities held in PD Mandala Cipaku Ciamis, such as observation of the method of product distribution and sales volume. (2) Documentation. "The document is a record of past events. Documents may be in the form of writings, drawings, or monumental works of a person or object of research. Documentation is used as an instrument for analysis to support research "(Sugiyono, 2019: 326). This documentation aims to obtain data related to research variables, namely the distribution channel cost and sales volume of PD Mandala Cipaku Ciamis in the form of financial statement data from 2017 to 2020. (3) Interview. This study uses in-depth interview techniques (in depth 
interview) in the form of semi-structured interviews (Sugiyono, 2019: 318). "In-depth interviews are often used to explore all the attributes of respondents or informants to explore information in depth" (Sandjaja \& Heriyanto, 2006: 148).

Data analysis used in this research are: (1) Descriptive Analysis. Descriptive analysis aims to create a systematic, factual and accurate description of the facts and characteristics of a particular population or region, in addition to descriptive analysis can describe the sample data taken in this study. (2) Normality Test. Normality test is a test conducted with the aim to assess the distribution of data in a group of data or variables, whether the distribution of data is normally distributed or not. (3) Coefficient of Determination (R2). The formulation of correlation coefficient is done by using comparison between the variation described by the total variation. The coefficient of determination is calculated by squaring the correlation coefficients that have been found, and then multiplied by $100 \%$. The coefficient of determination (determinant) is expressed in percent (Sugiyono, 2019: 207). R2 is called the coefficient of determination or coefficient determinant, conducted to know the percentage that contribute to the influence of independent variables simultaneously to the dependent variable. (4) Test t (Partial Test). The statistical test $t$ basically shows how far the influence of an independent variable individually in explaining the variation of the dependent variable. In this research used to know the influence of distribution channel cost to sales volume of snack at PD Mandala Cipaku Ciamis.

\section{Results and Discussion}

The study was conducted on PD Mandala having its address at Selacai, Dusun Cinutug, Selacai Village, Cipaku Subdistrict, Ciamis Regency. The company that produces snack foods such as mine cakes, fried basso, pastries and other food products, the company was established since 1992 and still operates to date.

1. Descriptive Analysis

PD Mandala Cipaku Ciamis which is one of the biggest snacks producer in Cipaku Ciamis, in its distribution can not be separated from the distribution activities. The distribution channel at the snack company is very important to facilitate the distribution of snacks to reach the hands of consumers on time. Companies must develop and design effective and appropriate distribution channels used in increasing the sales volume of snacks in the hope of achieving maximum profit.

The following explanation about the type of distribution channel used by PD Mandala, that is direct producer to consumer, producer to retailer then to consumer of PD Mandala using this distribution channel which is still direct distribution channel just use the intermediary of retailer who make direct purchasing to producer with big enough amount to be directly sold to consumers in retail or in smaller quantities and producers through wholesalers / sales to retailers and then consumers using this intermediary resulted in an increase in the number of product demand from consumers in the area that cooperates in marketing PD Mandala products, the wider the distributor will increase the distribution cost to be incurred by the company but provide an increase to the company's sales volume that will generate maximum profit.

Based on the date of statistical tests non-parametric Kolmogorov Smirnov data variable $\mathrm{X}$ (distribution channel costs) and variable $\mathrm{Y}$ (sales volume) has a significance value of $0.682>0.05$ then the data declared normal distribution.

3. Simple Regression Analysis 
Model Unstandardized Coefficients Standardized Coefficients T Sig.

From the result of analysis the influence of distribution channel cost to sales volume shows that independent variable (independent) that is Channel Charges Distribution (X), have contribution equal to $98,6 \%(0,986 \times 100 \%)$ to dependent variable that is Sales Volume $(\mathrm{Y})$, while the rest of $1.4 \%$ is influenced by other factors outside of this study.

4. Test $t$ (Partial Test)

Based on the results of testing with SPSS can be seen that the value of $t$ arithmetic is 14.626, while the value of $\mathrm{t}$ table is known ( $\mathrm{Dk}=\mathrm{N}-2)$ with a fault rate of 0.05 is 3.18245 then obtained $t$ value of $14.626>t$ table 3.18245 with significance $0.001<0.05$ then it can be concluded that Ho is rejected and Ha accepted.

From the calculation result using SPSS program based on simple regression table obtained variable cost distribution channel with sig value equal to 0,001. Compared with the probability value of 0.05 is greater than the probability sig value (0.05> o.001), then Ho is rejected and $\mathrm{Ha}$ is accepted, meaning the relationship of both variables has a positive and significant effect. Proved that the cost of distribution channels have a positive and significant impact on the increase in sales volume of PD Mandala Cipaku Ciamis. So it can be concluded that the increase in sales volume will not be separated from the level of distribution channel costs used by the company, the high low sales volume of the company can be measured from how much the cost of distribution channels used.

From result of analysis influence of distribution channel cost to sales volume show that coefficient coefficient value R square (R2) equal to 0,986 which is result of squaring of correlation coefficient $(0,993 \times 0,993)$. In this study the value of coefficient of determination Adjusted R Square that is equal to 0.986. This means independent variables (Channel Distribution Channel X), have a contribution of 98.6\% (0.986 x $100 \%$ ) to the dependent variable (Sales Volume (Y), while the rest of $1.4 \%$ is affected by other factors outside of this study.

The cost of distribution channels has an effect of $98.6 \%$ on the increase in sales volume. Distribution channels as an element of the marketing mix have an important role in marketing the product and achieve the company's goal to get the maximum profit. Without proper selection of distribution channels, the expected sales volume will not be well aligned. Another influence of $1.4 \%$ is influenced by factors outside of this study, such as product quality, price level offered by producers to consumers and how producers promote their goods with the aim of attracting consumers to buy goods produced by the company.

For statistical test $\mathrm{t}$ is basically used to show how far the influence of independent variables is the cost of distribution channels to the dependent variable is the volume of sales partially. Hypothesis based on $t$ test is formulated as follows:

Ho $=$ The distribution channel has no positive and significant effect on the PD sales volume. Mandala Cipaku Ciamis

$\mathrm{Ha}=$ Distribution channels have a positive and significant effect on PD sales volume. Mandala Cipaku Ciamis

Based on the results of testing with SPSS can be seen that the value of $t$ arithmetic is 14.626 , while the value of $t$ table is known $(\mathrm{Dk}=\mathrm{N}-2)$ with 0,05 error level is 
3.18245 then obtained $t$ value counted $14.626>t$ table 3.18245 with significance 0.001 $<0.05$ then it can be concluded that Ho is rejected and Ha accepted.

The test results are in accordance with research conducted by Sari (2019) with the title Influence Channel Distribution Against Sales Volume of Cement Products PT. Semen Tonasa In Pangkep with the results of quantitative analysis showed that based on the results of multiple regression analysis obtained equation: $\mathrm{Y}=(-5052,710)+$ $3,410 \mathrm{X} 1+(-4,867) \mathrm{X} 2+109,894 \mathrm{X}_{3}$. The most dominant variable affecting sales volume is variable of number of packing plant ( $\left.\mathrm{X}_{3}\right)$ with coefficient equal to 109,894. The value of adjuted determination coefficient $\mathrm{R}$ Square is 0,999 , it means all independent variable that is Distribution Cost (X1), Number of Distributors (X2), Number of Packing Plant $\left(\mathrm{X}_{3}\right)$ have contribution together $99,9 \%$ to dependent variable (Y) sales volume. The remaining $0.1 \%$ is influenced by other factors not included in the study. Hypothesis testing using t test shows that each independent variable has a strong and significant influence on the dependent variable.

\section{Conclusion}

Based on the results of research and discussion above, it can be concluded as follows: (1) The cost of distribution channels and sales volume of PD Mandala snacks from 2017 to 2020 tends to increase and stabilize by $10 \%$ per year, increasing the cost of the distribution channel indicating the wider market share. PD Mandala in its distribution using the type of dual distribution channels, namely direct distribution channels and indirect distribution channels to market their products in the factory environment hinggga entire market share into the area of marketing. (2) The influence of distribution channel cost to sales volume shows that the value of coefficient of determination R square (R2) of 0.986 so it can be concluded that the relationship between variable $\mathrm{X}$ (Channel cost distribution) to variable $\mathrm{Y}$ (Sales volume) of $98.6 \%$ is very strong, and $1.4 \%$ is influenced by other factors outside of this research like other marketing mix. Hypothesis testing using t test shows that the independent variable has a strong and significant influence on the dependent variable.

\section{REFERENCES}

Alma, Bukhari \& Prianca. (2011). Management of marketing and marketing services. Bandung: Alfabeta.

Gitosudarmo, Indriyo. (2008). Marketing management, second edition. Yogyakarta: BPFE-Yogyakarta.

Gymnasiar \& Kertajaya. (2004). Doing business with heart. Jakarta: Mark Plus \& CO.

Kartajaya \& Sula. (2006). Sharia marketing. Bandung: PT Mizan Pustaka

Kotler. (2007). Marketing management, volume 12th edition. Jakarta: PT Index.

Martono, Nanang. (2020). Social research methods: key concepts. Jakarta: PT Raja Grafindo Persada.

Hang on, Freddy. (2002). Creating effective marketing plan. Jakarta: PT Gramedia Pustaka Utama.

Rhenald Kasali., Et.al. (2017). Entrepreneurship module for strata 1. Bandung: PT Mizan Publika. 
Sandjaja, B \& Heriyanto, Albertus. (2006). Research guides. Jakarta: Achievement of its librarian.

Sari, Wita, Desi. (2019). Influence of distribution channel to sales volume of cement products pt. Semen tonasa in pangkep.Makasar. Unpublished thesis.

Sugiyono. (2019). Combined research methods (mixed methods), fifth printing. Bandung: Alfabeta.

Sujarweni, V. Wiratna. (2019). The research methodology is complete, practical and easy to understand. Yogyakarta: New Library Press.

Sunyoto, Danang. (2017). The basics of marketing management: concepts, strategies, and cases. Yogyakarta: CAPS.

Suryabrata, Sumadi. (2004). Research methodology. Jakarta: PT Raja Grafindo Persada.

Sutojo, Siswanto. (2009). Marketing management for non-marketing executives, second edition. Jakarta: PT Damar Mulia Pustaka.

Swastha, Basu. (2005). Sales management, twelfth printing. Yogyakarta: Liberty.

Swastha \& Irawan. (2005). Modern marketing management, second edition, fourth printing. Yogyakarta: Liberty.

Shakir, Muhammad. (2006). Shari'ah marketing. Bandung: Mizan Pustaka.

Tjiptono, Fandy. (2008). Marketing strategy. Jakarta: PT Index of Gramedia Group. 
